\title{
Applications of Chlorine Dioxide Gas for Control of Bacterial Soft Rot in Tomatoes
}

\author{
Michael J. Mahovic, University of Florida, Department of Plant Pathology, Gainesville; Joel D. Tenney, ICA Tri- \\ Nova Corporation, LLC, Newnan, GA; Jerry A. Bartz, University of Florida, Department of Plant Pathology, \\ Gainesville
}

\begin{abstract}
Mahovic, M. J., Tenney, J. D., and Bartz, J. A. 2007. Applications of chlorine dioxide gas for control of bacterial soft rot in tomatoes. Plant Dis. 91:1316-1320.

Chlorine dioxide $\left(\mathrm{ClO}_{2}\right)$ gas was generated from a mixture of sodium chlorite and ferric chloride plus water (impregnated into zeolite) in a Tyvek sachet over a 2- or 24-h period. The gas was distributed by a fan over wound-inoculated tomato fruit (Lycopersicon esculentum) enclosed in a sealed aluminum pressure cooker. Within $24 \mathrm{~h}$ of inoculation with $6 \log _{10} \mathrm{CFU}$ of Erwinia carotovora subsp. carotovora per wound and storage at 22 to $24^{\circ} \mathrm{C}$, bacterial soft rot was observed on $>80 \%$ of the nontreated wounds (10 wounds/fruit and 4 or 6 fruit/treatment). By contrast, wounds that had been exposed to an atmosphere containing up to $99 \mathrm{mg} \mathrm{ClO}_{2}$ during a 2- or 24$\mathrm{h}$ period remained firm and dry with no evidence of bacterial activity or soft rot. After $72 \mathrm{~h}$ of incubation, wounds exposed to $88 \mathrm{mg} \mathrm{ClO}_{2}$ produced over $24 \mathrm{~h}$ or $99 \mathrm{mg} \mathrm{ClO}_{2}$ produced over 2 $\mathrm{h}$ were free of decay, whereas bacterial soft rot was observed in ca. $12 \%$ and less than $5 \%$ of wounds treated with $0.75 \mathrm{mg}$ or $7.5 \mathrm{mg}$, respectively, for either 2 or $24 \mathrm{~h}$. Wounds that had not been inoculated remained free of bacterial soft rot throughout the entire storage period. Wounds exposed to the highest doses of $\mathrm{ClO}_{2}, 88 \mathrm{mg} / 24 \mathrm{~h}$ or $99 \mathrm{mg} / 2 \mathrm{~h}$, became bleached and sunken. Additionally, the stem scars on these fruit became cracked, sunken, and bleached. The intact cuticle was not visibly affected, and there was no observed change in overall fruit color. $\mathrm{ClO}_{2}$ gas may be effective for controlling postharvest decays of fruit that have been inoculated prior to or during harvest.
\end{abstract}

Additional keywords: disease management, Pectobacterium carotovorum (syn.), vegetable crops

Currently, the primary methods for controlling postharvest decays in fresh market tomatoes (Lycopersicon esculentum Mill.) are preventative. Measures are taken throughout harvest and handling to minimize any mechanical injury that can break the tomato surface; harvest crews are not allowed into a field until the plant canopy is dry, in order to minimize pathogen dispersal in the field; and recommendations are that water handling systems at packinghouses (such as in dump tanks and flumes) contain 150 to $200 \mathrm{ppm}$ free chlorine at a $\mathrm{pH}$ of 6.5 to $7.5(4,23,25)$. This concentration of chlorine will prevent the accumulation of microorganisms in the water and prevent the movement of viable microorganisms among incoming fruit (cross contamination). However, free chlorine, even at much higher concentrations than those recommended, only functions to control pathogen dispersal. It is ineffective at sanitizing inoculated wounds when applied after the inoculation has occurred

Corresponding author: M. Mahovic

E-mail: mmahovic@gmail.com

Accepted for publication 17 May 2007.

doi:10.1094/PDIS-91-10-1316

(C) 2007 The American Phytopathological Society
(13). Similarly, aqueous solutions of a more specific oxidizing agent, chlorine dioxide $\left(\mathrm{ClO}_{2}\right.$, used as a gas dissolved in a liquid) (30), have been tested for sanitizing dump tanks against several postharvest pathogens of apples (26), pears (27), potatoes (31), cucumbers (24), and citrus (7). While decontamination was successful in several studies where pathogens were surface inoculated, internalized organisms would be less susceptible to biocidal treatment (2). Also, cost and off-gassing issues have prevented the technology from becoming commercially adopted.

As a gas treatment, $\mathrm{ClO}_{2}$ is commercially used to sterilize medical equipment that is unsuited to heat or irradiation treatment, as a bleaching agent in the paper industry, and for several other purposes (30). Recently, $\mathrm{ClO}_{2}$ gas fumigation was used to eradicate spores of Bacillus anthracis that were embedded in the carpeting of the Hart Senate Office building (28). Experimentally, $\mathrm{ClO}_{2}$ gas successfully killed spores of $B$. thuringiensis that were contaminating wood, paper, epoxy, and plastic surfaces (14). $\mathrm{ClO}_{2}$ gas has also been applied to fresh fruits and vegetables that were inoculated with certain human pathogens. Commodities investigated include citrus (7), strawberries (17), green peppers (15), and apples (11). The reduction in recoverable bacteria associated with these treatments ranged from $2 \log _{10}$ to 8 $\log _{10}$. It is unclear if $\mathrm{ClO}_{2}$ gas would be effective at eliminating plant pathogens from inoculated wounds. The objective of the work reported here was to evaluate the ability of $\mathrm{ClO}_{2}$ as a gas treatment, instead of as an aqueous solution, to sanitize wounds on tomato fruit that had been inoculated with the causal agent of bacterial soft rot. A portion of this manuscript has been reported (22).

\section{MATERIALS AND METHODS}

Inoculum. The postharvest disease of tomato fruit caused by Erwinia carotovora subsp. carotovora, bacterial soft rot, is the most important cause of decay on tomatoes grown in Florida (19), and was used as the model pathogen in this system. Florida strain SR-38 of E. carotovora subsp. carotovora was grown and maintained as described previously (1). Aqueous cell suspensions of E. carotovora subsp. carotovora were prepared from up to 3day-old cultures on nutrient agar (NA) plates or from 16- to 20-h-old shake cultures in nutrient broth plus $2 \%$ dextrose. Spent culture media was removed from the cell suspension by centrifugation. The NA culture was suspended in sterile tap water ( $\mathrm{pH} 8.2$ ), sedimented into a pellet by centrifugation, and then the pellet was resuspended in sterilized tap water. The centrifugation and resuspension steps were repeated two times, such that each broth culture was washed in this manner a total of three times. The concentration of bacteria in the final suspension was estimated by comparing the optical density $(\lambda=600$ $\mathrm{nm})$ to a previously determined cell count, as previously described (3).

Fruit. Tomato fruit (either of an unknown cultivar or 'Florida-47') were kindly supplied by the DíMare Corporation (Tampa, FL). Fruit were stored at $13^{\circ} \mathrm{C}$ and $90 \%$ relative humidity $(\mathrm{RH})$. From 18 to $24 \mathrm{~h}$ before each experiment, fruit were removed from cool storage and held in the laboratory overnight to allow the fruit to warm to ambient temperature (22 to $24^{\circ} \mathrm{C}$ ). Fruit were selected for each test based on color (29) and freedom from major defects.

Inoculation. A scalpel was used to remove a strip of epidermis to a depth of ca. $1 \mathrm{~mm}$ from the equator of the fruit at 10 evenly spaced locations. Each of the resulting wounds had a surface area of ca. 2 
$\mathrm{cm}^{2}$. The wounds were inoculated by immersing the entire fruit for $3 \mathrm{~s}$ in an aqueous cell suspension of E. carotovora subsp. carotovora containing $6 \log _{10} \mathrm{CFU} / \mathrm{ml}$, or by adding a $10-\mu l$ droplet of an $8 \log _{10}$ $\mathrm{CFU} / \mathrm{ml}$ suspension of the pathogen to each wound. After inoculation, fruit were dried at room temperature on a laboratory bench for 15 to $30 \mathrm{~min}$, until the wound surface lost visible surface water.

Treatment chamber. An aluminum, 21liter pressure cooker was modified by the attachment of a direct current box fan (12 $\mathrm{V}$, blade diameter $=72 \mathrm{~mm}$ ) to the bottom surface of the lid (Fig. 1). Power wires were threaded through a rubber plenum that replaced the safety pressure-release plug (Fig. 1, arrow). The wires were connected to a DC power supply that was plugged into a standard wall outlet. Duct tape was placed over the pressure regulator stems and the pressure release valves. In preliminary tests, the relative humidity generated by a sample of 5 or 10 green tomatoes in the chamber was recorded (WatchDog model 250, Spectrum Technologies, Inc., Plainfield, IL).

Production of chlorine dioxide gas. A chlorine dioxide gas production system was supplied by ICA TriNova Corporation, LLC (Newnan, GA). The system consisted of a folded Tyvek envelope, one side of which contained dry granules of sodium chlorite impregnated into zeolite, a clay mineral, and the second side contained a proprietary acid activator, also impregnated into zeolite (20). Immediately prior to a test, a sachet would be unfolded and briefly shaken to mix the contents. The mixture began producing chlorine dioxide gas through acidic disproportionation. The gas would diffuse freely through the envelope into the atmosphere of the treatment chamber. For the experiments reported herein, sachets were designed to release a known quantity of chlorine dioxide $(\mathrm{mg})$ over a given time interval ( 2 or $24 \mathrm{~h}$ ).

The amount of $\mathrm{ClO}_{2}$ produced in a chamber was indirectly determined by a titration procedure that measured the amount of $\mathrm{I}_{2}$ in a KI solution that was allowed to react with the gas. As the gas

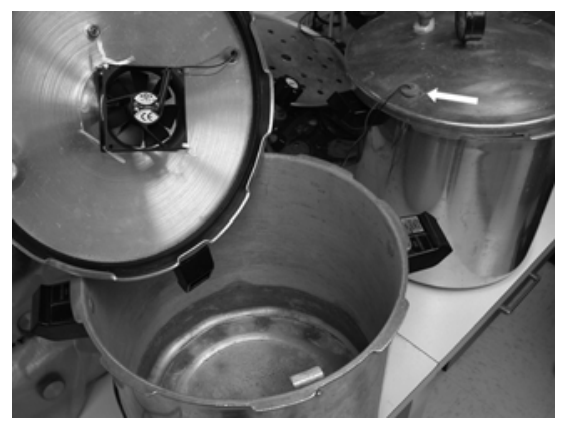

Fig. 1. Aluminum 21-liter pressure cookers modified for use as treatment chambers. Fans added to ensure circulation. Rubber plenums used to seal fan wiring ports (arrow, top right) and pressure vents in lid. dissolved in this solution, it oxidized the iodide ion to $\mathrm{I}_{2}$. The amount of standard thiosulfate solution needed to reduce this $\mathrm{I}_{2}$ back to iodide ion indicated the amount of chlorine dioxide involved (6). The KI solutions had been buffered to $\mathrm{pH} 7.0$ to assure that the $I_{2}$ produced was the result of a single electron transfer from an iodide ion to a chlorine dioxide molecule. In the determination of the output of the various sachets, they were enclosed in a glass jar with KI solutions. At various time intervals, a sachet would be transferred from one jar to another (with a fresh KI solution) until 2 or $24 \mathrm{~h}$ had elapsed. Based on the titration (6), production of $\mathrm{ClO}_{2}$ from a sachet was plotted for a 2- or 24-h period (Fig. 2). Each plot was based on three to six separate, but identically prepared, sachets. The sachets differed from each other by weight and/or ratio of the two reactants.

Treatments. Inoculated fruit were placed in each chamber. Sachets of the appropriate dose were mixed and then taped to the inside of the chamber's lid. The lid was immediately attached and twisted shut to form an airtight seal. The fan was activated and a timer was started. After 2 or $24 \mathrm{~h}$, the fruit were removed and placed in storage for observation. Tests were conducted three separate times, with six fruit in the first set and four fruit in each of the last two. All fruit had 10 inoculated wounds each. The results of the three tests were handled as replicates in the statistical analysis. Initially, fruit were treated with $0.75 \mathrm{mg} \mathrm{ClO}$ over a period of 2 or 24 h. Next, fruit were treated with $7.5 \mathrm{mg}$ $\mathrm{ClO}_{2}$ for 2 or $24 \mathrm{~h}$. Finally, fruit were treated with an approximate $10 \times$ dose of $88 \mathrm{mg} \mathrm{ClO} 2 / 2$ h or $99 \mathrm{mg} \mathrm{ClO} / 24$ h. Parallel to each trial in a separate chamber, two fruit were wounded and inoculated with $E$. carotovora subsp. carotovora (positive control), and two different fruit were wounded and not inoculated (negative control).

Fruit evaluation. After treatment, fruit were arranged on $37 \times 51 \mathrm{~cm}$ trays which were placed inside a clear polyethylene bag $(61 \times 76 \mathrm{~cm}, 1.5 \mathrm{~mm}$ thick). The bag was loosely rolled shut and stored at room temperature $\left(22\right.$ to $\left.24^{\circ} \mathrm{C}\right)$. The relative humidity ( $>99 \%$, with visible condensation on inner bag surfaces) and temperature favored the development of bacterial soft rot. Fruit were observed at 24-h intervals, and percent disease incidence (number of wounds with soft rot/number of wounds inoculated $\times 100$ ) and fruit appearance were recorded. At each observation, fruit with $100 \%$ decay were discarded and trays were placed in fresh bags for further storage, to minimize secondary spread of the pathogen. At the end of the 72-h observation period, a sampling of tissues encompassing the wound surface and about $2 \mathrm{~mm}$ of underlying tissue were cut from asymptomatic wounds and analyzed for the presence of E. carotovora subsp. carotovora. Samples from each wound were placed in a separate test tube containing $5 \mathrm{ml}$ of sterilized phosphate buffer solution (PBS, $\mathrm{pH} 7.0$ ) with $0.1 \%$ Tween 80 (wt/vol), and then held on a rotary shaker for $20 \mathrm{~min}$ (21). A $10-\mu l$ sample of the suspension in each tube was spotted onto a plate of crystal violet polypectate (CVP) medium (9) and observed for the development of characteristic pits within $24 \mathrm{~h}$. Pitting would be considered a "positive" result, evidence that colonies of the pathogen were present. For each treatment, all asymptomatic wounds, up to $10 \%$ of the total wounds in each treatment, were examined in this manner.

Statistical analysis. Each treatment was performed individually and in parallel with a set of positive and negative controls. Data for each treatment are presented as

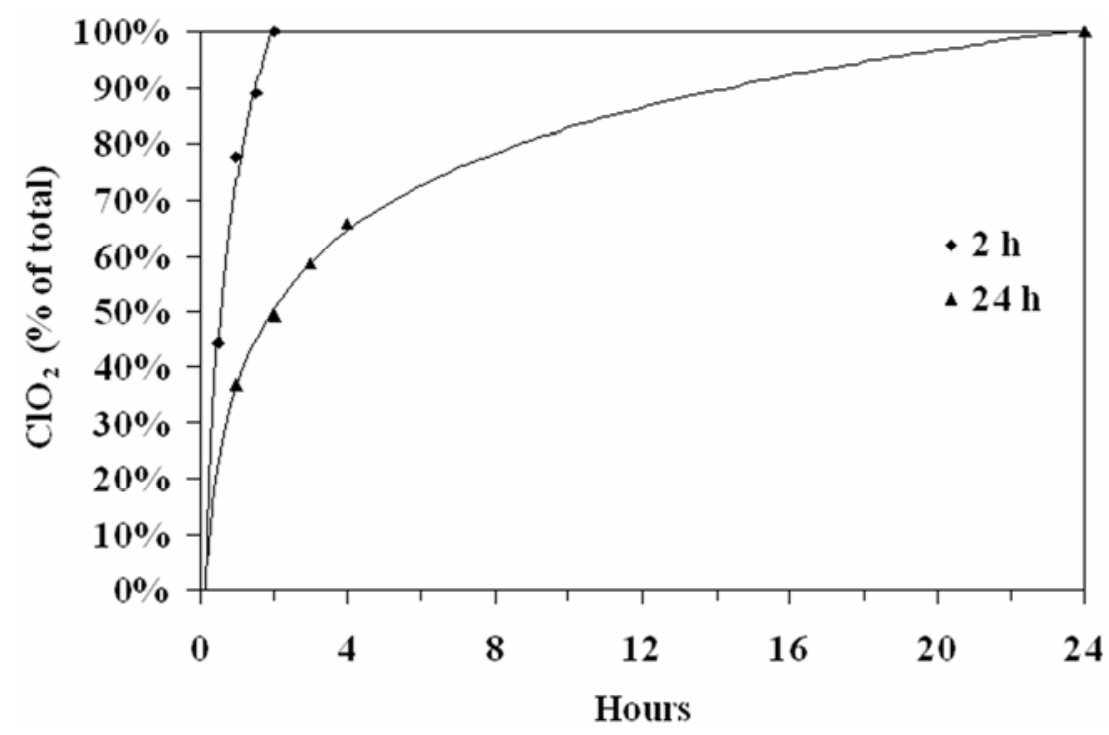

Fig. 2. Production of $\mathrm{ClO}_{2}$ versus time from dry materials designed to produce the gas within a 2- or 24-h period. Data points represent percentage of $\mathrm{ClO}_{2}$ produced at a given time compared with total produced by termination of the reaction ( 2 or $24 \mathrm{~h})$. 
the averaged incidence of decay, with incidence defined as: (wounds with symptoms of decay)/(total number of inoculated wounds) $\times 100 \%$. Total decay across all replicates was then averaged and standard deviations were calculated, followed by calculation of $95 \%$ confidence intervals (represented graphically as error bars). Values were tabulated and analyzed using the statistical "analysis tool pack" software

\section{RESULTS}

In $\mathrm{ClO}_{2}$ sachet-release studies, $57 \%$ of the total $\mathrm{ClO}_{2}$ expected to be produced from a $7.5 \mathrm{mg} / 24 \mathrm{~h}$ sachet had reacted with the sink within the first $2 \mathrm{~h}$ of exposure (Fig. 2). By 4 h, $75 \%$ of the predicted dose had reacted with iodide. The rate of $\mathrm{ClO}_{2}$ capture decreased with time. For the 0.75 $\mathrm{mg} / 24 \mathrm{~h}$ sachet, 41 and $57 \%$ of the expected total release was detectable at 2 and $4 \mathrm{~h}$, respectively. For all $24-\mathrm{h}$ sachets, only a minor amount of $\mathrm{ClO}_{2}$ was captured during the last $8 \mathrm{~h}$. For both of the sachets designed to generate $\mathrm{ClO}_{2}$ over a 2-h period, $77 \%$ of the total $\mathrm{ClO}_{2}$ released was captured by the end of the first hour, and the remaining $23 \%$ was detected by the end of the second hour. The chlorite/acid activator reaction in the 2-h delivery sachets continued to produce $\mathrm{ClO}_{2}$ after $2 \mathrm{~h}$, but because the chambers were opened and the fruit removed at $2 \mathrm{~h}$, any subsequent $\mathrm{ClO}_{2}$ output was not involved in the treatment. The $88 \mathrm{mg} / 24 \mathrm{~h}$ and $99 \mathrm{mg} / 2 \mathrm{~h}$ sachets generated $\mathrm{ClO}_{2}$ at similar rates, as a percentage of total production, to the 0.75 and 7.5 sachets (data not shown). The distinctive odor of $\mathrm{ClO}_{2}$ (30) was observed only after application of the two highest doses, or when tomato fruit were not enin MS Excel.

closed with the $\mathrm{ClO}_{2}$ generating sachets. By contrast, a slight odor was always noticed immediately after mixing the sachet contents. No odor was observed after any of the $0.75-$ or $7.5-\mathrm{mg}$ treatments of the tomato fruit.

Bacterial soft rot was observed on roughly $80 \%$ of the wounds of positive control fruit within $24 \mathrm{~h}$ of inoculation. By $48 \mathrm{~h}$, most of the lesions had expanded beyond the edge of the wound, and by $72 \mathrm{~h}$ after treatment, symptoms of bacterial soft rot were observed on $91 \%$ of the wounds (Fig. 3). In contrast, on noninoculated fruit, bacterial soft rot was observed on $2.7 \%$ of the wounds.

Symptoms of bacterial soft rot were not observed on wounds treated with $0.75 \mathrm{mg}$ $\mathrm{ClO}_{2} / 2 \mathrm{~h}$, after $24 \mathrm{~h}$ of post-treatment storage. Wound surfaces appeared light colored and firm. By $72 \mathrm{~h}$ after treatment, water-soaking, discoloration, and tissue softening were observed on $10 \%$ of the wounds (Fig. 3). The area affected within each wound was often less than $100 \%$ of the injured surface, although records of percentage of surface area decayed were not kept. Lesions expanded as rapidly as did those on the nontreated fruit. When the $\mathrm{ClO}_{2}$ dose was increased to $7.5 \mathrm{mg} / 2 \mathrm{~h}, 2 \%$ of the wounds had evidence of bacterial soft rot by $72 \mathrm{~h}$ of post-treatment storage. With the 0.75 and $7.5 \mathrm{mg} / 24 \mathrm{~h}$ treatments, 13 and $0.7 \%$ decay, respectively, was observed after $72 \mathrm{~h}$ of post-treatment storage (=96 h postinoculation). Fruit treated with $88 \mathrm{mg} / 24 \mathrm{~h}$ or $99 \mathrm{mg} / 2 \mathrm{~h}$ were free of decay at $72 \mathrm{~h}$ after treatment (data not shown).

In one series of treatments $(7.5 \mathrm{mg} / 2 \mathrm{~h})$, two replicates of positive control fruit were observed to have wounds that were asymp-

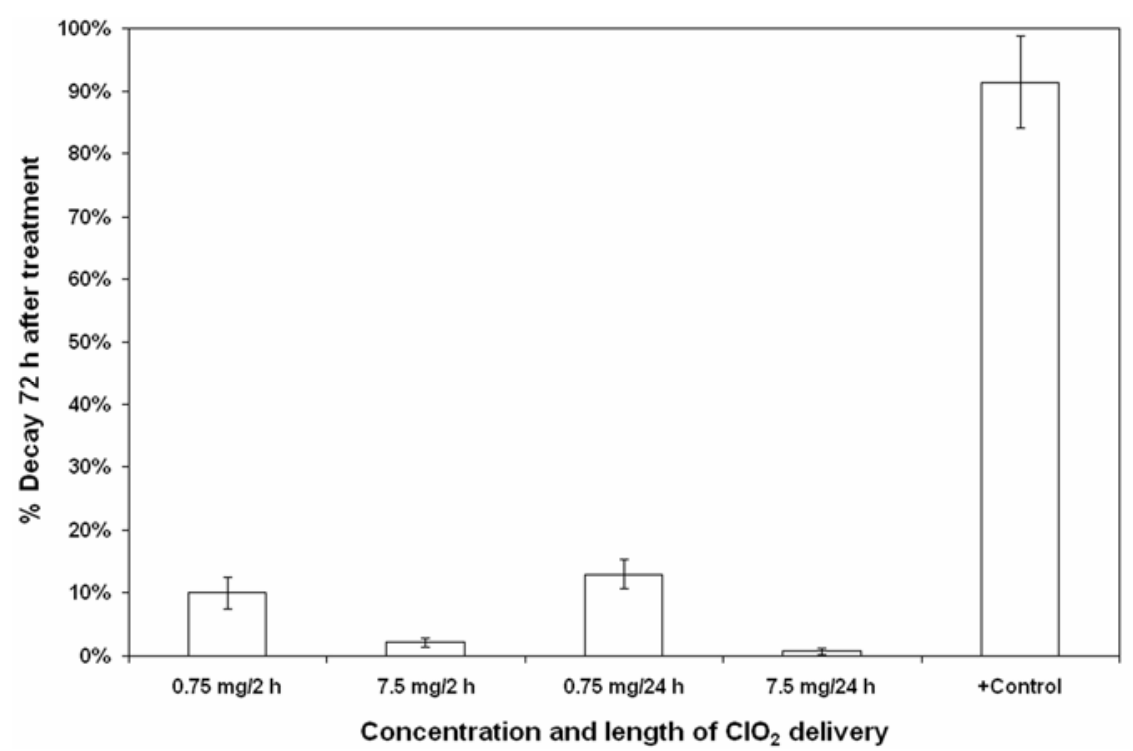

Fig. 3. Incidence of bacterial soft rot in tomato fruit (wounds with symptoms/total wounds) that had been wound-inoculated with Erwinia carotovora subsp. carotovora, treated with $\mathrm{ClO}_{2}$ gas, and then stored for $72 \mathrm{~h}(=74,96$, or $24 \mathrm{~h}$ postinoculation for fruit treated for $2 \mathrm{~h}, 24 \mathrm{~h}$, or untreated, respectively). "+Control" reflects data from inoculated fruit not exposed to $\mathrm{ClO}_{2}$. Error bars represent confidence intervals at $P=0.05$. tomatic for bacterial soft rot (10 and 20\%; the third replicate had $100 \%$ decayed). When plated to CVP, all of these wounds were positive for characteristic bacterial colonies of E. carotovora subsp. carotovora within $24 \mathrm{~h}$. All other wounds on positive control fruit showed decay. Conversely, no pitting was observed when extracts from wounds sampled from noninoculated fruit were similarly plated. Among treated fruit, for the 2-h treatments of 0.75 - and $7.5-\mathrm{mg}$ doses of $\mathrm{ClO}_{2}$, pits were produced on CVP medium by extracts from 35.7 and $35.0 \%$ of the asymptomatic wounds tested, respectively. In contrast, 5.3 or $75.0 \%$ of the samples from the $7.5-$ or $0.75-\mathrm{mg}$ dose $/ 24 \mathrm{~h}$ treatments, respectively, yielded soft rot bacteria (Fig. $4)$. In contrast, pits were not observed on plates spotted with extracts from negative wounds sampled from fruit treated with 88 $\mathrm{mg} \mathrm{ClO} / 24 \mathrm{~h}$ or $99 \mathrm{mg} \mathrm{ClO} / 2 \mathrm{~h}$.

For all doses of $\mathrm{ClO}_{2}$ evaluated, the intact cuticle of treated fruit appeared similar to that of nontreated fruit. However, wounds on fruit treated with 0.75 and 7.5 $\mathrm{mg} \mathrm{ClO}_{2}$ had visible bleaching when fruit were removed from the chamber (Fig. 5A), and became desiccated within $24 \mathrm{~h}$ of posttreatment storage (Fig. 5B). Stems and stem scars, including the corky ring around the stem scars, on fruit treated with 88- or 99-mg doses were bleached and mildly sunken (Fig. 5C and D). The bleaching of stems or stem scars was mild or not observed after the $0.75-$ and $7.5-\mathrm{mg}$ treatments.

\section{DISCUSSION}

The traditional and current method used for sanitizing tomato fruit at packinghouses is addition of the strong oxidizer chlorine to the handling and wash water (5). This treatment is very effective for preventing accumulation of microorganisms in the water, as well as preventing cross-contamination of fruit entering the system. However, the inability of aqueous chlorine solutions to eliminate soft rot bacteria from wounds is well known (12). In three previous tests, free chlorine concentrations of $\geq 500 \mathrm{ppm}$ applied to woundinoculated tomatoes led to soft rot incidences of 26,42 , and $82 \%$ as compared with water-washed controls of 58,58 , and $74 \%$ (4). Acidified sodium chlorite (ASC) at $100 \mathrm{ppm}$ chlorite yielded 10,18, and $46 \%$ in the same tests. Burnett et al. (8) noted that human bacterial pathogens, many of which are gram negative and have many other characteristics similar to $E$. carotovora subsp. carotovora, cannot reliably be removed from fresh fruits and vegetables by even the strongest surface sanitizers. Bartz et al. (4) noted that development of bacterial soft rot in inoculated wounds on tomato fruit could not be prevented by treatment with up to $600 \mathrm{mg}$ of free chlorine/liter at $\mathrm{pH} 7.0$, perhaps because the chlorine solution displaced the 
inoculum deeper into the wound. Thus, the ability of $\mathrm{ClO}_{2}$ gas to prevent soft rot development at inoculated wounds, as shown in the present study, represents a potential tool for significant postharvest disease control.

The usual method for applying $\mathrm{ClO}_{2}$ gas to sanitize fruits and vegetables includes either batch or continuous application (20). In both methods, the dose of gas applied is based on the volume of the chamber. With batch treatments, a measured amount of $\mathrm{ClO}_{2}$ gas is injected into the chamber containing the product to be treated. A fan circulates the air to keep the $\mathrm{ClO}_{2}$, which is heavier than air, uniformly distributed. At the end of the treatment, any remaining gas is removed by exhaust fans. In a continuous treatment, $\mathrm{ClO}_{2}$ is injected as needed throughout treatment to maintain a specified head-space concentration of the gas, which is usually measured with a spectrophotometer. At the end of the treatment, the remaining $\mathrm{ClO}_{2}$ must be purged from the system, as with the batch method.

$\mathrm{ClO}_{2}$ applied to wound-inoculated tomato fruit as investigated in this study was produced from two dry materials that were mixed at the beginning of the treatment (20). The amount of gas produced in this system depended on the type and ratio of the materials. The design of the Tyvek sachets containing the materials produces a designated amount of $\mathrm{ClO}_{2}$ within 2 or 24 $\mathrm{h}$, with the actual rate of production mostly independent of the total production value. Most of the production occurs in the first hour after the materials are mixed for a 2-h sachet $(77.8 \%)$, or after $4 \mathrm{~h}$ for a $24-\mathrm{h}$ sachet $(56.7$ to $75.0 \%) \cdot \mathrm{ClO}_{2}$ production curves for the sachets used in this study were based on capture of $\mathrm{ClO}_{2}$ in a solution of potassium iodide. Excess KI $(>10 \times$ the amount needed to react with the expected concentration of $\mathrm{ClO}_{2}$ ) was dissolved in the solution to prevent undesirable reactions such as the formation of higher oxidation states of iodine (6). For the $7.5 \mathrm{mg} \mathrm{ClO} / 2 \mathrm{~h}$ treatment, a total of $0.36 \mathrm{mg} / \mathrm{liter}$, or about $130 \mathrm{ppm}$ by volume $(\operatorname{ppm} v)$, was captured by the iodide solution within $2 \mathrm{~h}$. This is $>400 \times$ more concentrated than the concentration at which $\mathrm{ClO}_{2}$ gas odor becomes evident in air, which is $\geq 0.3$ to $1.0 \mathrm{ppm} v$ (30). On a weight basis, this concentration converts to about $0.8 \mu \mathrm{g} / \mathrm{liter}$, or $0.038 \mu \mathrm{g} / 21$ liter chamber. The absence of odor when the chambers were opened in this study following the 0.75 or $7.5 \mathrm{mg} \mathrm{ClO}$ treatments suggested that the gas had either been absorbed by, or reacted with, the enclosed tomatoes. As such, purging unreacted chlorine dioxide as per the batch or continuous applications was unnecessary. At the end of a closed treatment with these doses in packinghouses, worker protection issues should not exist. By contrast, when high concentrations ( 88 or $99 \mathrm{mg} \mathrm{ClO}_{2}$ ) were the chambers were opened. However, these concentrations produced phytotoxicity on the stem scars and wounds on the fruit and would not be suitable for use in packinghouses.

In a portion of the treated tomato wounds (which was apparently dependent on dose and length of time of application), $\mathrm{ClO}_{2}$ gas treatment delayed disease onset, or completely prevented decay. Even the lowest dose of $\mathrm{ClO}_{2}$ evaluated in this study rial soft rot, since no lesions were observed when the $0.75 \mathrm{mg} / 24 \mathrm{~h}$ chambers were opened. While the percentage of wounds with recoverable bacteria after treatment with either 0.75 or $7.5 \mathrm{mg} \mathrm{ClO}_{2}$ over $2 \mathrm{~h}$ applied, a faint odor was detectable when prevented the initial development of bacte-

were similar, increasing the delivery time of both $\mathrm{ClO}_{2}$ doses to $24 \mathrm{~h}$ significantly reduced the number of recoverable cells on fruit treated with $7.5 \mathrm{mg} \mathrm{ClO}$, but did not significantly affect the recoverable cells at the $0.75 \mathrm{mg} \mathrm{ClO}_{2}$ dose. Although treatment with $\mathrm{ClO}_{2}$ here demonstrated that it is effective in controlling decay due to $E$. carotovora subsp. carotovora, the minimum dose and delivery time needed to affect such reductions is unknown.

The greater potential efficiency of $\mathrm{ClO}_{2}$ gas, compared with either aqueous solutions of $\mathrm{ClO}_{2}(16,20)$ or chlorinated water, for treatment of inoculated wounds of fresh produce appears to be related to the ease of movement of the gas form of the oxidizer. White (30) noted that, at equilib-

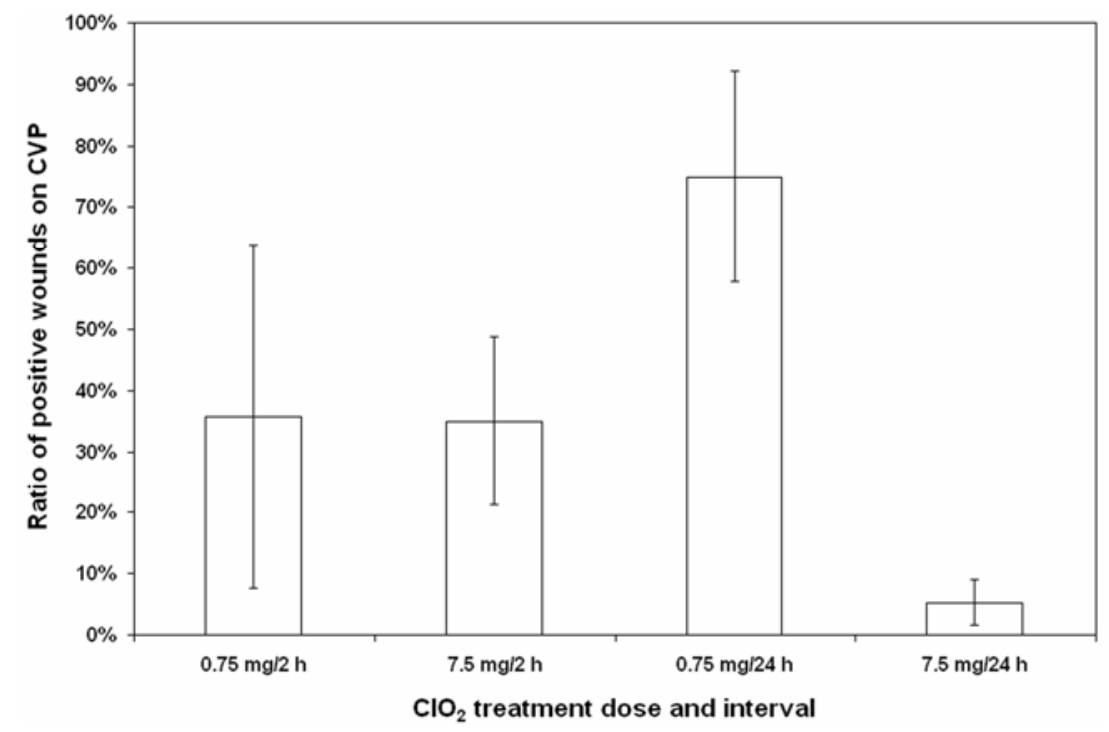

Fig. 4. Percentage of wounds yielding Erwinia carotovora subsp. carotovora based on development of bacterial colonies in characteristic pits on CVP media. Up to $10 \%$ of asymptomatic wounds on tomato fruit treated with $\mathrm{ClO}_{2}$ were evaluated for presence of the pathogen after $72 \mathrm{~h}$ of posttreatment storage. Error bars represent confidence intervals at $P=0.05$.

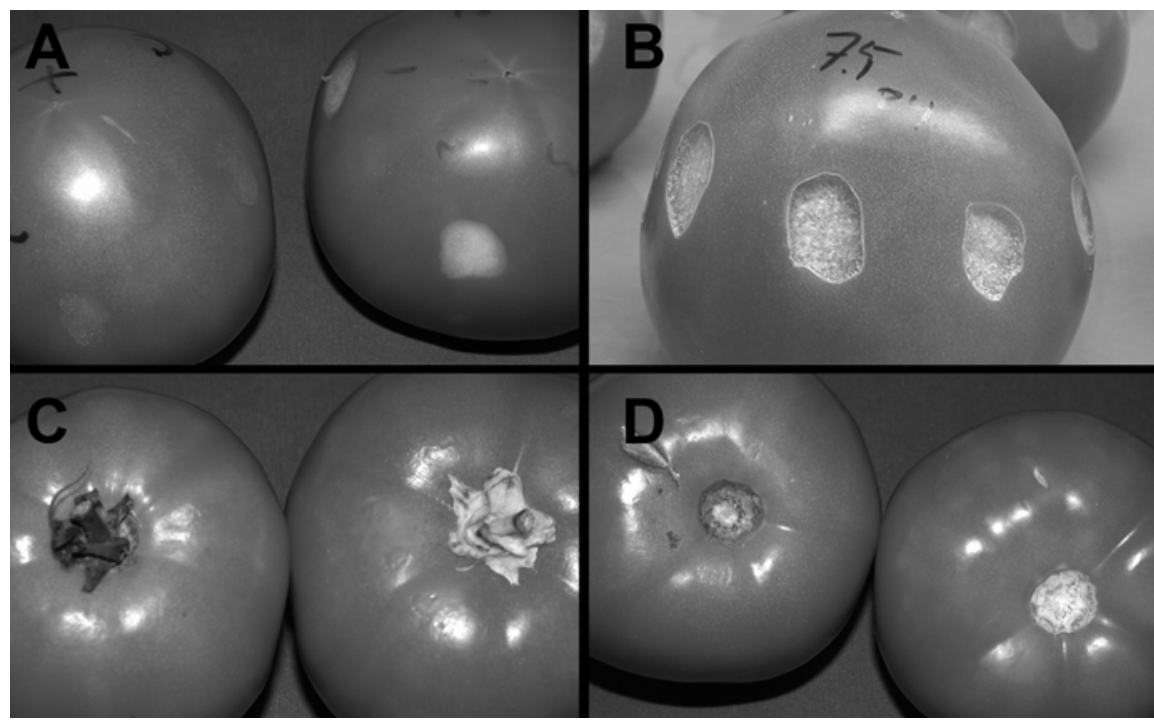

Fig. 5. Effects of $\mathrm{ClO}_{2}$ gas treatment on red tomato fruit. Fruit were treated with $0.75 \mathrm{mg}(\mathbf{A}$, immediately after treatment), $7.5 \mathrm{mg}\left(\mathbf{B}, 24 \mathrm{~h}\right.$ after treatment), or $88 \mathrm{mg}(\mathbf{C}$ and $\mathbf{D})$ of $\mathrm{ClO}_{2}$ per six fruit over 2 h. Fruit in frames A and B were wounded, while fruit in frames C and D were unwounded. In frames $\mathrm{A}, \mathrm{C}$, and D, the fruit on the left is an untreated control. 
rium, the concentration of $\mathrm{ClO}_{2}$ in water at $25^{\circ} \mathrm{C}$ was 23 times greater than in the air over the water. If the $\mathrm{ClO}_{2}$ that dissolved in the cell sap in wounds on tomato fruit in this study was continually removed by oxidation, then the accumulated dose that reacted with tissues and bacteria in the wounds should greatly exceed the amount that can be supplied through $\mathrm{ClO}_{2}$ gas dissolved in solution ( $3 \mathrm{mg} /$ liter is the maximum dose registered for use [20]). Moreover, the method by which the chlorine dioxide is supplied is fundamentally different in aqueous solutions than it is when supplied as a gas. With aqueous solutions, diffusion of fresh oxidant into the wound surface is slow, compared to a gaseous form of $\mathrm{ClO}_{2}$; DeBeer et al. (10) noted that the concentration of free chlorine in a biofilm was several times less than in the bulk fluid bathing the film. Equilibrium of chlorine between the water and the biofilm did not occur during the 1- to 2-h incubation period in that study. With gas applications of $\mathrm{ClO}_{2}$, active oxidant continuously and preferentially impinges on the water film in a wound. Based on the principles of Henry's Law for gas solubility in a liquid (18), the gas from the headspace continuously dissolves into the water films as the $\mathrm{ClO}_{2}$ already present reacts and no longer contributes to the partial pressure. The $\mathrm{ClO}_{2}$ will continue to dissolve into the liquid at a rate related to the remaining headspace concentration, essentially focusing the $\mathrm{ClO}_{2}$ in the intercellular spaces harboring inoculum of the pathogen.

$\mathrm{ClO}_{2}$ gas has potential as a postinoculation treatment of tomatoes for prevention of bacterial soft rot, and perhaps to inactivate other potentially hazardous bacteria. As such, this treatment could be used on packed fruit. Additional studies are needed with $\mathrm{ClO}_{2}$ gas to determine if it is effective against fungal pathogens of fruit, how it interacts with packaging materials, and how it might be dispersed through pallets of fruit.

\section{ACKNOWLEDGMENTS}

We thank the DíMare Corporation, Tampa, FL, for supplying the tomato fruit necessary for this study, and the Florida Tomato Committee for their cooperation and funding.

\section{LITERATURE CITED}

1. Bartz, J. A. 1981. Variation in the latent period of bacterial soft rot in tomato fruit. Phytopathology 71:1057-1062.
2. Bartz, J. A. 2006. Internalization and infiltration. Pages 75-94 in: Microbiology of Fruits and Vegetables. G. M. Sapers, J. R. Gorny, and A. E. Yousef, eds. CRC Press, Boca Raton, FL.

3. Bartz, J. A., and Crill, J. P. 1972. Tolerance of fruit of different tomato cultivars to soft rot. Phytopathology 62:1085.

4. Bartz, J. A., Eayre, C. G., Mahovic, M. J., Concelmo, D. E., Brecht, J. K., and Sargent, S. A. 2001. Chlorine concentration and the inoculation of tomato fruit in packinghouse dump tanks. Plant Dis. 85:885-889.

5. Bartz, J. A., and Tamplin, M. L. 2003. Sales of vegetables for fresh market: The requirement for hazard analysis and critical control points (HACCP) and sanitation. Pages 563-580 in: Postharvest Physiology and Pathology of Vegetables. 2nd ed. J. A. Bartz and J. K. Brecht, eds. Marcel Dekker, Inc., New York.

6. Blaedel, W. J., and Meloche, V. W. 1957. Elementary Quantitative Analysis: Theory and Practice. Row, Peterson and Co., Evanston, IL.

7. Brown, G. E., and Wardowski, W. F. 1984. Use of chlorine and chlorine dioxide in Florida citrus packinghouses to reduce inoculum of decay pathogens. Proc. Fla. State Hortic. Soc. 97:97-100

8. Burnett, S. L., Chen, J. R., and Beuchat, L. R. 2000. Attachment of Escherichia coli O157: $\mathrm{H} 7$ to the surfaces and internal structures of apples as detected by confocal scanning laser microscopy. Appl. Environ. Microbiol. 66:4679-4687.

9. Cuppels, D., and Kelman, A. 1974. Evaluation of selective media for isolation of soft-rot bacteria from soil and plant-tissue. Phytopathology 64:468-475.

10. DeBeer, D., Srinivasan, R., and Stewart, P. S. 1994. Direct measurement of chlorine penetration into biofilms during disinfection. Appl. Environ. Microbiol. 60:4339-4344.

11. Du, J., Han, Y., and Linton, R. H. 2003. Efficacy of chlorine dioxide gas in reducing Escherichia coli $\mathrm{O} 157: \mathrm{H} 7$ on apple surfaces. Food Microbiol. 20:583-591.

12. Eckert, J. W. 1977. Control of postharvest diseases. Ch. 9 in: Antifungal Compounds. M. R. Siegel and H. D. Sisler, eds. Marcel Dekker, New York.

13. Eckert, J. W., and Sommer, N. F. 1967. Control of diseases of fruits and vegetables by postharvest treatment. Annu. Rev. Phytopathol. 5:391432.

14. Han, Y., Applegate, B., Linton, R. H., and Nelson, P. E. 2003. Decontamination of Bacillus thuringiensis spores on selected surfaces by chlorine dioxide gas. J. Environ. Health 66:16-20.

15. Han, Y., Floros, J. D., Linton, R. H., Nielsen, S. S., and Nelson, P. E. 2001. Response surface modeling for the inactivation of Escherichia coli O157: $\mathrm{H} 7$ on green peppers (Capsicum annuum L.) by chlorine dioxide gas treatments. J. Food Prot. 64:1128-1133.

16. Han, Y., Linton, R. H., Nielsen, S. S., and Nelson, P. E. 2001. Reduction of Listeria monocytogenes on green peppers (Capsicum annuиm L.) by gaseous and aqueous chlorine dioxide and water washing and its growth at 7 degrees C. J. Food Prot. 64:1730-1738.

17. Han, Y., Selby, T. L., Schultze, K. K., Nelson, P. E., and Linton, R. H. 2004. Decontamination of strawberries using batch and continuous chlorine dioxide gas treatments. J. Food Prot. 67:2450-2455.

18. Henry, W. 1803. Experiments on the quantity of gases absorbed by water, at different temperatures, and under different pressures. Phil. Trans. Roy. Soc. London 93:29-42.

19. Jones, J. B., Jones, J. P., Stall, R. E., and Zitter, T. A. 1991. Compendium of Tomato Diseases. American Phytopathological Society, St. Paul, MN.

20. Linton, R. H., Han, Y., Selby, T. L., and Nelson, P. E. 2006. Gas-/vapor-phase sanitation (decontamination) treatments. Pages 401-435 in: Microbiology of Fruits and Vegetables. G. M. Sapers, J. R. Gorny, and A. E. Yousef, eds. CRC Press, Boca Raton, FL

21. Lukasik, J., Bradley, M. L., Scott, T. M., Hsu, W. Y., Farrah, S. R., and Tamplin, M. L. 2001 Elution, detection, and quantification of Polio I, bacteriophages, Salmonella montevideo, and Escherichia coli O157:H7 from seeded strawberries and tomatoes. J. Food Prot. 64:292297.

22. Mahovic, M., and Bartz, J. A. 2002. Improvements in sanitation of flumes or dump tanks in packinghouses. (Abstr.) Proc. Fla. State Hortic. Soc. 35-37.

23. Mahovic, M., Sargent, S. A., and Bartz, J. A. 2004. Identifying and controlling postharvest tomato diseases in Florida. IFAS Publishing, Document HS 866, University of Florida, Gainesville. Online publication.

24. Reina, L. D., Fleming, H. P., and Humphries, E. G. 1995. Microbiological control of cucumber hydrocooling water with chlorine dioxide. J. Food Prot. 58:541-546.

25. Ritenour, M. A., Sargent, S. A., and Bartz, J. A. 2002. Chlorine use in produce packing lines. IFAS Publishing, Document HS 761, University of Florida, Gainesville. Online publication.

26. Roberts, R. G., and Reymond, S. T. 1994. Chlorine dioxide for reduction of postharvest pathogen inoculum during handling of tree fruits. Appl. Environ. Microbiol. 60:28642868.

27. Spotts, R. A., and Peters, B. B. 1980. Chlorine and chlorine dioxide for control of d'Anjou pear decay. Plant Dis. 64:1095-1097.

28. U.S. Environmental Protection Agency. 2006 Pesticides: Topical \& Chemical Fact Sheets, Chlorine Dioxide Gas. Office of Pesticide Programs. Online publication.

29. United Fresh Fruit and Vegetable Association and the U.S. Department of Agriculture, A. M S. F. a. V. D. 1975. Color Classification Requirements in Tomatoes; U.S. Standards for Grades of Fresh Tomatoes. John Henry Company, Lansing, MI.

30. White, C. 1999. Handbook of Chlorination and Alternative Disinfectants. John Wiley \& Sons, New York.

31. Wyatt, G. M., and Lund, B. M. 1981. The effect of antibacterial products on bacterial soft rot of potatoes. Potato Res. 24:315-329. 